\title{
Predicting and Reducing Adverse Drug Reactions (ADRs)
}

\author{
Harold I. Zeliger
}

\begin{abstract}
All pharmaceutical drugs (PDs) have Adverse drug reactions (ADRs) associated with their use in some individuals. ADRs are a leading cause of morbidity and mortality in those using (PDs). It is well known that the number and severity of ADRs associated with the use of PDs are elevated by a number of parameters including age, gender, genetic makeup, polypharmacy, exposure to organic solvents, alcohol, tobacco or recreational drug use, diet, chronic inflammation, preexisting disease and ongoing emotional stress. All the parameters responsible for ADRs also increase oxidative stress (OS) as reflected by the Oxidative Stress Index (OSI). The OSI is hypothesized here to predict the likelihood and severity of ADRs.
\end{abstract}

Index Terms - Adverse drug reactions, drug side effects, oxidative stress, oxidative stress index.

\section{INTRODUCTION}

All pharmaceutical drugs (PDs) have Adverse drug reactions (ADRs) associated with their use and ADRs are a leading cause of morbidity and mortality in those using PDs [Kramer 1981; Alomar, 2014 and the references contained therein]. It is also known that the number and severity of ADRs associated with the use of these medications are elevated by a number of parameters which include include age, gender, genetic makeup, polypharmacy, exposure to organic solvents, alcohol, tobacco or recreational drug use, diet, chronic inflammation, preexisting disease and ongoing emotional stress exposures [Alomar, 2014; Lauschke and Ingelman-Sundberg, 2016; Alhawassi, et al., 2014; Gochfeld, 2017; Mendrick, et al., 2017; Kaufmann, et al., 2015; Sushko. et al., 2012; Grzybowski, et al., 2015; Kramer, 1981].

All the parameters associated with ADRs are also causative of increased levels of oxidative stress (OS). Total (OS) is associated, in a dose response relationship, with increased likelihood of disease onset and severity of disease [Zeliger, 2016]. It has recently been shown that the oxidative stress index (OSI), based upon responses to a detailed questionnaire that addresses all aspects of a person's OS level, is a predictor of both level of OS and likelihood of disease onset [Zeliger, 2019]. It is proposed here that the likelihood of ADR onset following the start of treatment with a pharmaceutical can be predicted using the OSI.

\section{METHODS}

Causes of ADRs and OS are well known and widely reported in the literature and representative references for

Published on October 27, 2019

H. I. Zeliger is with Zeliger Research, LLC 41 Wildwood Drive Cape Elizabeth, ME 04107, USA (e-mail: hiz@zeligercom). these are included here. The applicability of the OS to predicting disease onset is based upon a literature review of published studies of the causes of OS and the mechanistic relationships between OS and disease onset [Zeliger, 2016]. The OSI is obtained via the use of a questionnaire that probes genetics (family history, age, illnesses and conditions, clinical test results, environmental exposures, lifestyle, medications regularly taken, psychological stress, disease status and chronic symptoms [Zeliger, 2019].

\section{Results AND DisCUSSION}

\section{A. Oxidative Stress and Disease Prediction}

Elevated oxidative stress is well known to be a direct cause of non-communicable environmental diseases in all body systems as well as an indirect cause of infectious disease via undermining of the immune system. Total OS is increased in a dose response relationship no matter what the cause and total OS can come from any one or multiples of the parameters shown in Table 1 [Zeliger, 2016].

TABLE 1: OS ELEVATING FACTORS THAT PREDICT DISEASE ONSET.

\begin{tabular}{|l|l|}
\hline Genetics & $\begin{array}{l}\text { Many diseases are heritable. These include } \\
\text { those carried by DNA, as well as epigenetic } \\
\text { ones transmitted through the generations that } \\
\text { are not carried by DNA }\end{array}$ \\
\hline Age & OS increases naturally with age \\
\hline Weight & Excess body fat and obesity \\
\hline Current Illnesses & All concurrent illnesses \\
\hline $\begin{array}{l}\text { Psychological } \\
\text { Stress }\end{array}$ & $\begin{array}{l}\text { Chronic emotional stress, anxiety and } \\
\text { depression }\end{array}$ \\
\hline $\begin{array}{l}\text { Current } \\
\text { Symptoms }\end{array}$ & $\begin{array}{l}\text { All symptoms of environmental exposure, } \\
\text { disease, and inflammation }\end{array}$ \\
\hline Clinical Test Data & $\begin{array}{l}\text { All clinically determined parameters out of the } \\
\text { "normal" range }\end{array}$ \\
\hline Inflammation & Chronic inflammation \\
\hline Medication taken & $\begin{array}{l}\text { All prescription and over-the-counter } \\
\text { medications regularly taken }\end{array}$ \\
\hline Diet & $\begin{array}{l}\text { High regular intake levels of sugar, salt, } \\
\text { processed foods, saturated fats and chemical } \\
\text { food additives. }\end{array}$ \\
\hline Lifestyle & $\begin{array}{l}\text { Alcohol, tobacco or recreational drug use and } \\
\text { living in an area with high air pollution and } \\
\text { water pollution }\end{array}$ \\
\hline Radiation & $\begin{array}{l}\text { Environmental chemical exposures to } \\
\text { chemicals at home, school or work. }\end{array}$ \\
\hline & $\begin{array}{l}\text { Ionizing as well as non-ionizing radiation } \\
\text { exposure }\end{array}$ \\
\hline
\end{tabular}

Serum malondialdehyde, the biomarker most often used to measure OS, though a valuable indicator of OS that is stable in serum and easily analyzed for, can vary widely depending upon what a person ate, pollutants he or she may have been exposed to, medications being used, state of emotional status and other OS elevating parameters prevalent when serum is drawn. These variables can cause serum MDA levels to vary by as much as 19 percent over a six day period [Nielsen, et al., 1997]. The Oxidative Stress 
Index (OSI), which is described below, eliminates the uncertainties associated with OS measurement.

\section{B. Adverse Drug Reactions}

All pharmaceuticals cause ADRs and produce symptoms that vary from mild to severe to life threatening. The most common symptoms of ADRs are shown in Table 2 [Kramer, 1981]. More severe ADRs include Type 2 diabetes, numerous cancers, cardiovascular diseases, neurological diseases, respiratory diseases and immunological effects.

\begin{tabular}{|} 
TABLE 2: COMMON ADR SYMPTOMS \\
\hline Nausea \\
\hline Vomiting \\
\hline Diarrhea \\
\hline Abdominal pain \\
\hline Rash \\
\hline Skin itch \\
\hline Drowsiness \\
\hline Insomnia \\
\hline Weakness \\
\hline Headache \\
\hline Dizziness \\
\hline Trembles \\
\hline Twitching \\
\hline Fever \\
\hline
\end{tabular}

All the symptoms in Table 2 are associated with OS [Zeliger 2016, Zeliger 2019].

Some people suffer higher incidences and increased severities of ADRs than others. Factors that contribute to these enhanced effects include all those listed as OS raising in Table 1; age, gender, pregnancy, genetics, drug dose, toxic chemical exposure, polypharmacy, frequency of pharmaceutical drug use, allergy, multimorbidity, chronic inflammation, alcohol use, smoking, body weight and fat distribution, diet and environmental chemical exposures [Alomar, 2014; Lauschke and Ingelman-Sundberg, 2016; Alhawassi, et al., 2014; Gochfeld, 2017; Mendrick, et al., 2017; Kaufmann, et al., 2015; Sushko. et al., 2012; Grzybowski, et al., 2015]. Though it is beyond the scope of this paper to fully explore each of these factors in detail, the following briefly describes each of these and the reader is referred to the cited literature for further discussions.

\section{Age}

Older people are more likely to experience ADRs [Alomar, 2014]. There are several reasons for this. As people age, they become more likely to have increasing health problems and thus take increasing numbers of PDs (polypharmacy). With increasing age, the amount of water retained by the body decreases resulting in increases of concentrations of hydrophilic drugs. Since the ratio of fat to muscle tissue increases with age, lipophilic drugs are stored by the body in greater quantities. With aging, liver function declines, lowering the ability of the body to metabolize drugs and the ability of the kidneys to excrete drugs and metabolites into urine also is decreased [Alomar, 2014].

ADRs are more pronounced in children than in adults due to variabilities in metabolic capabilities and the lack of often inadequate evaluations testing in the young. In this regard, infants are particularly vulnerable [Clavenna and Bonati; 2008].

\section{Gender}

Compared to men, women have lower body weight, smaller organ sizes, higher levels of body fat, different gastric motility and varying metabolic and drug elimination rates [Alomar 2014]. Women also have increased numbers of acute and chronic health problems than men do [Legato, 1998]. ADR effects are different for pregnant women, as total blood volume increases, resulting in the altering of concentration levels of drugs taken during pregnancy and impacting the pharmacokinetics and pharmacodynamics of the drugs [Duncombe, et al., 2008]

\section{Multi-Morbidity}

ADR prevalence increases with the number of concomitant diseases one ails from [Alomar, 2014] due to the introduction of additional OS elevating factors and the possibilities of drug interactions.

\section{Pharmaceutical Drug Use \& Polvpharmacy}

All PDs cause ADRs and elevate OS. Accordingly, elevated drug dose, greater frequency of drug use and increased number of drugs regularly used (polypharmacy) all elevate OS, [Zeliger, 2016 and the references contained therein].The liver and kidneys are responsible for metabolism and elimination of toxins. The constant insult by daily drug intake challenges the abilities of these organs to effectively function. Also, ADRs to PDs used frequently lead to additional drug use to counteract those ADRs. PDs administered regularly to treat chronic diseases or to lower disease symptoms are prescribed to produce steady state body levels of these drugs, thus maintaining elevated OS levels.

\section{Toxic chemical exposure}

Environmental exposures to toxic chemicals have been shown to cause diseases of all body systems and organs, including all diseases associated with ADRs [Grzybowski et al., 2015; Sushko, et al., 2012]. For example, exogenous lipophilic chemical exposures are associated with metabolic, cardiovascular and neurological disease onset in dose response relationships. [Grova, et al., 2019; Lind, et al., 2019 Lee, et al., 2018; ] and hydrophilic exogenous chemical absorption causes numerous cancers, respiratory and neurological diseases [Yegambaram, et al., 2015; Fisseler-Eckhoff, et al., 2011; Caffo, et al., 2014].

These chemicals, which include persistent organic pollutants such as PCBs, chlorinated pesticides, polybrominated biphenyls and dioxins; phthalates; Bisphenol A; heavy metals including lead, mercury, chromium, arsenic, nickel and cadmium; polynuclear aromatic hydrocarbons; benzene, toluene, xylenes and other hydrocarbons; water chlorination by-products; air pollutants; water pollutants; and numerous others, all elevate OS [Zeliger. 2016].

Mixtures of chemicals have also been shown to induce the onset of numerous diseases, even when the concentrations of 
the individual components of the mixtures are below their known toxic levels. Such enhanced effects are observed when chemical mixtures contain at least one lipophilic and one hydrophilic component [Zeliger, 2003; Zeliger, 2011]. Some PDs are lipophilic while others are hydrophilic. Almost all, however, contain excipients to facilitate absorption, maintain stability, color coding and other purposes. The combinations of drugs and excipients set up lipophilic/hydrophilic mixtures that can contribute to toxic effects at lower than expected concentrations. Also, the lipophilic and hydrophilic components of toxic mixtures need not be simultaneously absorbed. Lipophilic species are soluble in body fats and can are retained for longer periods of time (up to decades for persistent organic pollutants) than hydrophilic species and not induce toxicity until a hydrophilic species is sequentially absorbed [Zeliger and Lipinski, 2015]. Accordingly, a lipophilic PD can combine with a hydrophilic species from another source when it is absorbed and a hydrophilic PD can combine with a lipophilic chemical present in the body that is not part of the drug formulations. Both such combinations can induce mixture effects.

\section{Radiation}

It is well known that ionizing radiation, $\mathrm{x}$-rays and gamma rays, break chemical bonds in the body and form free radicals that elevate OS. Lower energy ultraviolet [Goswami, et al., 2013] and microwave [Megha, et al., 2015] radiation exposures as well as very low energy radiofrequency [Cahill and Elder 1984] and extremely low frequency, electrical power line emitted, electromagnetic waves [Simco and Mattson, 2004] also lead to elevated oxidative stress and have been associated with disease.

\section{Chronic Inflammation}

Chronic inflammation can be caused by chronic disease, continual exposure to exogenous toxins, lifestyle choices and other OS raising parameters [Zeliger, 2016]. OS induces inflammation and inflammation leads to OS, setting up a vicious cycle of chronic inflammation [Reuter, et al., 2010]. Chronic inflammation increases cancer risk by impacting every step of tumorigenesis from initiation to tumor promotion and ultimately to metastatic progression [Ikemura, et al 2013].

ADRs are known initiators of inflammation, a few examples of which are cutaneous eruptions [Hoetzenecker, et al., 2016], drug-induced fever [Vodovar, et al., 2014] and vascular effects [Kroschinsky, et al., 2017].

\section{Lifestyle Choices}

Lifestyle choices including smoking, alcohol use, recreational drug use and diets high in sugar, salt, saturated fats and processed foods all contribute to elevated OS [Zeliger 2016] and also affect ADRs [Alomar, 2014; Hukkanen, et al., 2005; de Boer, et al., 2015].

\section{Excess Body Fat}

Excess body fat provides absorption sites for lipophilic PDs. and serves as a storage site for these. Fats also enhance the absorption of lipophilic PDs across cell membranes. Accordingly, the action of lipophilic PDs, as well as the severity of ADRs in people with excess body fat is both enhanced and prolonged thus increasing the severity of ADRs [Alomar, 2014].

\section{Genetics and epigenetics}

Genetic background is an accepted component of the probability of the onset of numerous diseases, including hypertension, diabetes, obesity and neurodegenerative disorders all of which are associated with elevated OS and ADRs [Balmus, et al., 2016]. Susceptibility to OS is also determined by genetic background, either by directly elevating OS, or by undermining the body's antioxidant defense systems leading to increases in OS [Du, et al., 2012; Gunther, et al., 2018].

Epigenetic effects, those heritable changes that do not involve an altered DNA sequence, have also been shown to be attributable to PDs [Pirmohamed and Park, 2001; Csoka and Szyf 2009; Kacevska et al., 2011; Hou, et al., 2012]. ADRs known to be associated with epigenetic effects include numerous cancers, diabetes, Alzheimer's disease, Parkinson's disease, osteoporosis, obesity, liver damage and teratogenic malformations. All these are known to be associated with elevated OS [Zeliger, 2016].

\section{Oxidative Stress Index (OSI)}

All disease is both a cause and a consequence of oxidative stress. Hence, total OS has been identified as an indicator of the likelihood of disease onset and severity, and is directly related to total OS in a dose response relationship, as discussed above. Total OS may be caused by a combination of genetic load, environmental toxic chemical and radiation exposures, lifestyle, psychological stress, disease prevalence and symptoms, medications regularly taken and chronic inflammation [Zeliger, 2016].

As discussed above, all parameters that are causative of OS are also associated with increased ADRs. It is hypothesized here that the OS status of an individual can be used to predict the likelihood and severity of adverse effects associated with use of PDs via the use of the OSI. The OSI, based upon responses to a detailed questionnaire, addresses all aspects of a person's OS level can not only predict likelihood of disease [Zeliger, 2019], but also can be used to predict ADR effects.

Determining steady state OS status via the OSI is valuable for both the patient and the clinician so that, if elevated, can be used to dictate disease and ADR prevention and treatment actions that can be taken to maintain health. When applied to ADR consideration, it can suggest alternative treatment protocols for patients with high OSI levels. The OSI offers the opportunity to accomplish this by producing a steady state profile of a person's OS status and by determining one's OSI as function of time, can demonstrate whether recommended treatment is being effective.

To determine one's OSI, the person, or surrogate, simply checks the items on the questionnaire that apply to her or him and the total number of checks equals the OSI. The following scale has been proposed as indicative of the likelihood of new disease onset [Zeliger 2019]. The OSI is shown in Table 3. 
TABLE 3: THE OXIDATIVE STRESS INDEX (OSI) QUESTIONNAIRE.

\begin{tabular}{|c|c|}
\hline OSI Level & Disease Likelihood \\
\hline $0-15$ & Low \\
\hline $16-30$ & Moderate \\
\hline $31-45$ & Probable \\
\hline 46 or higher & Likely \\
\hline
\end{tabular}

\section{FAMILY HISTORY:}

Put one check for each parent, sibling (sister or brother) or grandparent who has or had each of the diseases or conditions identified.

\begin{tabular}{|l|l|}
\hline & $\begin{array}{l}\text { Parent with neurological disease - Alzheimer's, Parkinson's, Lou } \\
\text { Gehrig, ADHD or Autism }\end{array}$ \\
\hline & Parent with diabetes \\
\hline & Parent with heart disease, heart attack or stroke \\
\hline & Parent with asthma or COPD \\
\hline & Parent with allergies - hay fever, animals, food or chemicals \\
\hline & Parent with cancer \\
\hline $\begin{array}{l}\text { Siblings with neurological disease - Alzheimer's, Parkinson's or } \\
\text { Lou Gehrig (ALS), }\end{array}$ \\
\hline ADHD or Autism \\
\hline & Siblings with diabetes \\
\hline & Siblings with heart disease, heart attack or stroke \\
\hline & Siblings with asthma or COPD \\
\hline & Siblings with allergies - hay fever, animals, food or chemicals \\
\hline & Siblings with cancer \\
\hline $\begin{array}{l}\text { Grandparents with neurological disease - Alzheimer's, } \\
\text { Parkinson's or Lou Gehrig, }\end{array}$ \\
\hline ADHD or Autism \\
\hline & Grandparents with diabetes \\
\hline & Grandparents with heart disease, heart attack or stroke \\
\hline & Grandparents with asthma or COPD \\
\hline & $\begin{array}{l}\text { Grandparent with allergies - hay fever, animals, food or } \\
\text { chemicals }\end{array}$ \\
\hline & Grandparent with cancer \\
\hline
\end{tabular}

Total Family History Checks

GENDER: $\quad$ Female

Male

AGE:

Check all age boxes that apply. If, for example, you are 55 years old check the first two boxes. If you're 82, check all 5 of these boxes.

\begin{tabular}{|l|l|}
\hline & 40 or older \\
\hline & 50 or older \\
\hline & 60 or older \\
\hline 70 or older \\
\hline & 80 or older \\
\hline
\end{tabular}

\section{WEIGHT:}

If you are overweight from your recommended weight, check all the weight boxes that apply. If, for example you are 40 pounds over your recommended weight, check the first three boxes and add three checks to the total. Find your recommended weight on the weight chart at the end of the OSI checklist.

\begin{tabular}{|l|l|}
\hline & $10-20$ pounds overweight \\
\hline & $21-40$ pounds overweight \\
\hline & $31-60$ pounds overweight \\
\hline $61-80$ pounds overweight \\
\hline & 81 or more pounds overweight \\
\hline
\end{tabular}

ILLNESSES and CONDITIONS:

Check all illnesses or conditions that you have been diagnosed with and currently have.

\begin{tabular}{|l|l|}
\hline & Acne \\
\hline & ADHD (Attention Deficit Hyperactivity Disorder) \\
\hline & AIDS or HIV \\
\hline & Alcohol addiction \\
\hline & Allergic rhinitis (sinus inflammation) \\
\hline & ALS (Lou Gehrig's disease) \\
\hline & Anemia \\
\hline & Anorexia \\
\hline & Anxiety disorder \\
\hline & Appetite loss \\
\hline & Arthritis \\
\hline & Asthma \\
\hline & Autism and ASD \\
\hline & Autism or autism spectrum disorder (ASD) \\
\hline & Benign prostate hyperplasia (enlargement - BPH) \\
\hline & Bipolar disorder \\
\hline & Bronchitis (chronic) \\
\hline & Bulimia \\
\hline & Bulging or herniated disc \\
\hline & Carpal tunnel syndrome \\
\hline
\end{tabular}

Cancer - Check all that apply. If stage three, for example, check first three

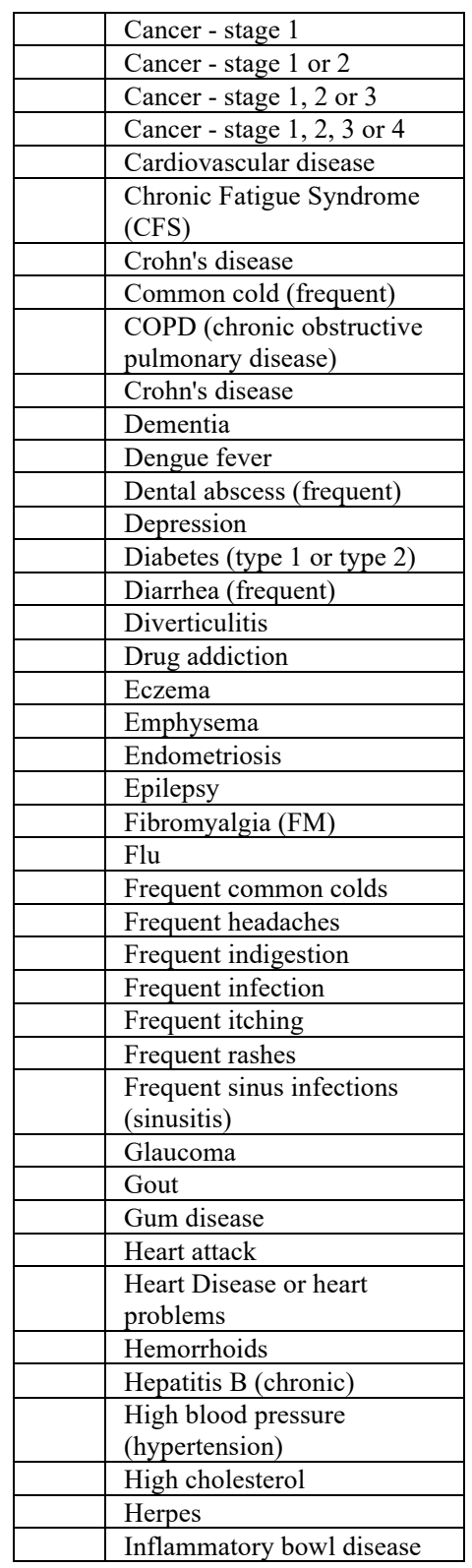




\begin{tabular}{|c|c|}
\hline & $\begin{array}{l}\text { Irritable bowel syndrome } \\
\text { (IBS) }\end{array}$ \\
\hline & Kidney disease \\
\hline & Leukemia \\
\hline & Liver cirrhosis \\
\hline & Liver disease \\
\hline & Lupus \\
\hline & Lyme disease \\
\hline & Macular degeneration \\
\hline & Malaria \\
\hline & $\begin{array}{l}\text { Metabolic syndrome (pre- } \\
\text { diabetes) }\end{array}$ \\
\hline & $\begin{array}{l}\text { Middle ear infection } \\
\text { (frequent) }\end{array}$ \\
\hline & Migraine headaches \\
\hline & $\begin{array}{l}\text { Multiple chemical sensitivity } \\
\text { (MCS) }\end{array}$ \\
\hline & Multiple sclerosis \\
\hline & Obesity \\
\hline & Osteoarthritis \\
\hline & Osteoporosis \\
\hline & Parkinson's disease \\
\hline & $\begin{array}{l}\text { Periodontal disease (swollen } \\
\text { or bleeding gums) }\end{array}$ \\
\hline & $\begin{array}{l}\text { Post-traumatic stress } \\
\text { disorder (PTSD) }\end{array}$ \\
\hline & $\begin{array}{l}\text { Rocky Mountain spotted } \\
\text { fever }\end{array}$ \\
\hline & Psoriasis \\
\hline & Rosacea \\
\hline & Schizophrenia \\
\hline & Seizures \\
\hline & $\begin{array}{l}\text { Sexually transmitted disease } \\
\text { (STD) }\end{array}$ \\
\hline & Shingles \\
\hline & Sjogren's syndrome \\
\hline & Sleep apnea \\
\hline & Stroke \\
\hline & TB (Tuberculosis) \\
\hline & Thyroid disease \\
\hline & Tourette syndrome \\
\hline & Tremors \\
\hline & Ulcers \\
\hline & Varicose veins \\
\hline & West Nile Fever \\
\hline & Yellow fever \\
\hline & Zika \\
\hline
\end{tabular}

Write in the names of any other illnesses you have that were not listed above and check those.

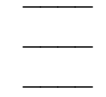

Total Disease Checks

\section{DISEASE START:}

How many of the diseases checked above started in

\begin{tabular}{|l|l|}
\hline & The past 2 years? \\
\hline & The past 5 years? \\
\hline & The past 10 years? \\
\hline
\end{tabular}

\section{SYMPTOMS:}

Check all the symptoms that you currently experience.

\begin{tabular}{|l|l|}
\hline & Abdominal pain (frequent) \\
\hline & Allergic reactions to chemicals \\
\hline & Allergic reactions to any foods \\
\hline
\end{tabular}

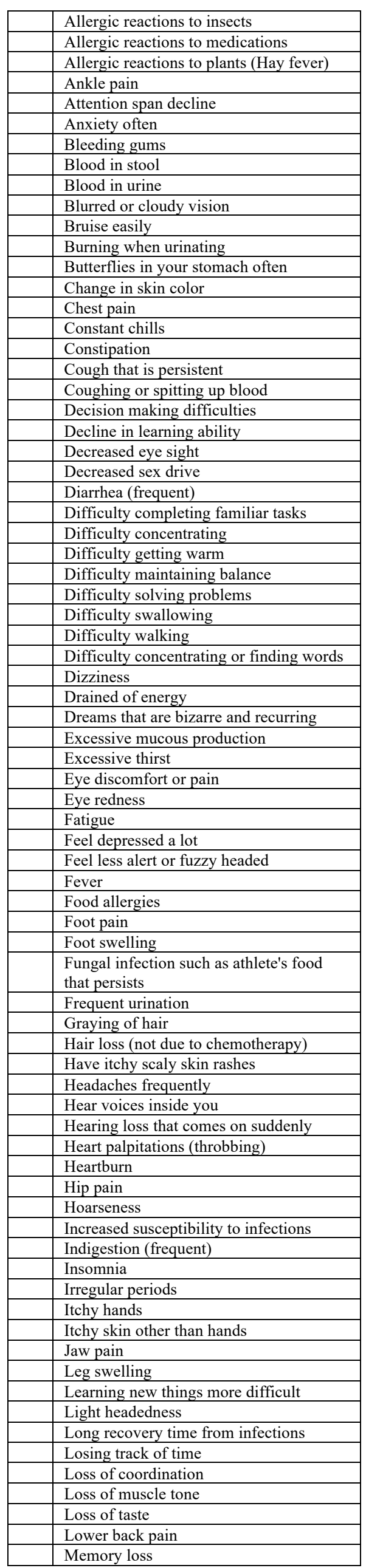




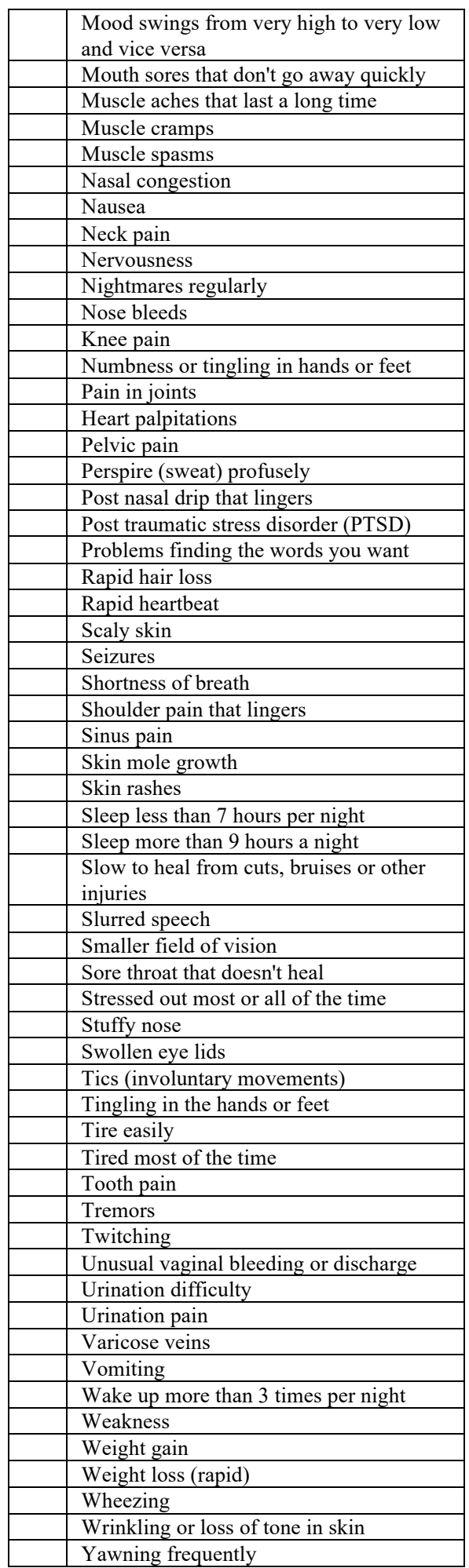

Total Symptoms Checks

\section{TEST RESULTS:}

The following address results obtained from tests doctors ordered done as part of annual examinations. Check all that apply to you.

\begin{tabular}{|l|l|}
\hline & High or low blood sugar \\
\hline & High or low BUN (blood urea nitrogen) \\
\hline & High or low calcium \\
\hline & $\begin{array}{l}\text { High or low carbon dioxide } \\
\text { (bicarbonate) }\end{array}$ \\
\hline & High or low chloride \\
\hline
\end{tabular}

\begin{tabular}{|l|l|}
\hline & High cholesterol \\
\hline & High or low creatinine \\
\hline & High glucose \\
\hline & High or low potassium \\
\hline & High PSA \\
\hline & High or low sodium \\
\hline & High triglycerides \\
\hline & Low blood oxygen \\
\hline & Low potassium \\
\hline
\end{tabular}

Total Test Results Checks

PRESCRIPTION MEDICINES REGULARLY TAKEN:

Check each of the boxes that apply. If you regularly take five prescription drugs, for example, check all of the first 5 items, so that the total number of items checked equals the total number of prescriptions regularly taken.

\begin{tabular}{|l|l|}
\hline & 1 prescription \\
\hline & 2 prescriptions \\
\hline & 3 prescriptions \\
\hline & 4 prescriptions \\
\hline & 5 prescriptions \\
\hline & 6 prescriptions \\
\hline & 7 prescriptions \\
\hline & 8 prescriptions \\
\hline & 9 prescriptions \\
\hline & 10 or more prescriptions \\
\hline & Have a heart pacemaker \\
\hline
\end{tabular}

Total Prescription Medicine Checks

DIET:

Check each item that applies to the foods that are part of your regular eat.

\begin{tabular}{|l|l|}
\hline & $\begin{array}{l}\text { Alcoholic beverages (beer, wine, spirits) more than 1 } \\
\text { drink per day }\end{array}$ \\
\hline & Artificial sweeteners for coffee or tea \\
\hline & $\begin{array}{l}\text { Canned or frozen cooked foods regularly eaten } \\
\text { (soups, pastas, meats) }\end{array}$ \\
\hline $\begin{array}{l}\text { Bread and pasta made primarily from white processed } \\
\text { flour }\end{array}$ & Fast food frequently eaten \\
\hline & Fewer than 3 fruits or vegetables a day \\
\hline & Grilled, smoked or blackened meat, chicken or fish \\
\hline $\begin{array}{l}\text { Food high in fat (whole milk, cheeses, foods cooked } \\
\text { with butter and animal fat) }\end{array}$ & $\begin{array}{l}\text { Often eat processed foods (bacon, hot dogs, salami, } \\
\text { sausages. deli meats }\end{array}$ \\
\hline Eat red meat more than 2 times a week \\
\hline $\begin{array}{l}\text { Eat foods high in sugar (sweetened drinks and } \\
\text { desserts) }\end{array}$ \\
\hline Salty food \\
\hline
\end{tabular}

Total Diet Checks

\section{LIFE STYLE:}

These items refer to where you live, the type of work you do and chemicals you may be exposed to.

\begin{tabular}{|l|l|}
\hline & Are a farmer that regularly uses pesticides \\
\hline & Burn wood for heat or for cooking \\
\hline & Constantly use a cell phone \\
\hline & Drink chlorinated water \\
\hline & Drink more than one alcoholic drink per day \\
\hline & Exercise less than one half hour a week \\
\hline & Have mold in your home \\
\hline $\begin{array}{l}\text { Have new (less than } 6 \text { months old) carpet in your } \\
\text { home }\end{array}$ \\
\hline
\end{tabular}




\begin{tabular}{|l|l|}
\hline & Have pets in your home that you are allergic to \\
\hline & Live down wind from a smoking industrial chimney \\
\hline & Live in a city with air quality alerts \\
\hline & $\begin{array}{l}\text { Live or work close to a cell tower } \\
\text { lines }\end{array}$ \\
\hline & Live near a heavily traveled highway or road \\
\hline & Live near a landfill \\
\hline & Live with a smoker \\
\hline & Regularly experience allergic reactions in your home \\
\hline $\begin{array}{l}\text { Regularly experience allergic reactions in your work } \\
\text { place }\end{array}$ & Regularly use room or furniture deodorants \\
\hline & Regularly play contact sports \\
\hline & Regularly sleep with lights or television on \\
\hline & $\begin{array}{l}\text { Regularly have outdoor lights shining into your } \\
\text { bedroom while sleeping }\end{array}$ \\
\hline
\end{tabular}

Tobacco use. Check all of the items that apply. For example, if you smoke one pack of cigarettes a day, check both of the first 2 items. If you smoke two packs a day, check all of the first 4 items.

\begin{tabular}{|l|l|}
\hline & Smoke 10 cigarettes or less daily (even just one) \\
\hline & Smoke a pack a day (20 cigarettes) \\
\hline & Smoke a pack and a half a day (30 cigarettes) \\
\hline & Smoke two packs a day (40 cigarettes) \\
\hline & Smoke more than two packs a day \\
\hline & Smoke 6 or more cigars a day \\
\hline & Use smokeless tobacco \\
\hline & Work as a toll booth collector \\
\hline & Work in very hot or very cold conditions regularly \\
\hline & Work in an adhesives or coatings manufacturing plant \\
\hline & Work in an agricultural chemical manufacturing plant \\
\hline & Work as an automobile, diesel or aircraft mechanic \\
\hline & Work with chemicals on the job regularly \\
\hline Work in a dusty environment regularly \\
\hline Work in a landfill \\
\hline & Work in a hair or nail salon \\
\hline & Work in metal refinery or mill \\
\hline & Work as a miner \\
\hline & Work in a noisy environment \\
\hline Work in a paint, lacquer, stain or varnish manufacturing plant \\
\hline & Work as a painter \\
\hline Work as a pilot or flight attendant \\
\hline Work as a pesticide applicator \\
\hline Work in a petroleum refinery \\
\hline Work in a plastics manufacturing plant \\
\hline Work in a plywood or particle board manufacturing plant \\
\hline $\begin{array}{l}\text { Work in a polluted environment (road paver, toll booth } \\
\text { operator, for example) }\end{array}$ \\
\hline Work in a water or sewage treatment plant \\
\hline Work in wood treatment plant \\
\hline ifestyle Checks \\
\hline
\end{tabular}

Total Lifestyle Checks

OSI, Total of All Checks

Though the OSI can predict the likelihood of disease onset, it cannot predict which disease will strike. Similarly, which specific ADRs and how severe they will be as a result of the administration of a particular PD cannot be predicted. The OSI can only demonstrate that there is a likelihood that ADRs will ensue and that their severities will be increased in those with high OSIs. Given that ADRs are concurrent with OS, ADR probability likelihoods will mirror those for disease onset.

The items in the OSI questionnaire are listed alphabetically, rather than by connections to specific parameters, in the different sections so that the responder is challenged to consider each item alone, rather than as part of a series, to which he/she could just check all or eliminate all from consideration.

\section{LIMITATIONS}

As with any hypothesis paper, clinical studies are required to confirm what is proposed. Such studies are currently in their preliminary stages.

\section{CONCLUSION}

ADRs are common when PDs are administered, as drugs are taken regularly to create steady state levels in the body. PDs can be lipophiles and facilitate the absorption of exogenous hydrophiles, or hydrophiles, whose toxicity is enhanced by presence of chemical lipophiles from other sources. ADRs associated with PDs, however, are hypothesized to be related not only to drug active ingredients and excipients, but also to all other endogenous and exogenous sources of OS elevating factors present. It is total OS, which can be easily measured via the OSI, that is responsible for the type, number and severity of resultant ADRs.

Predicting which ADRs will ensue from a particular PD use is extremely difficult, given the numbers and concentrations of endogenous and exogenous chemical species present in a person's body and the numerous mixtures that can arise from combinations of these. Associations of specific ADRs to particular PDs can, at this time, only be made through empirical observations due to the large numbers of OS elevating mixtures potentially present in the body at any given time.

The OSI can be used to demonstrate one's level of OS and suggest lifestyle changes that can be adopted to reduce OS and thus the numbers and severities of ADRs. It is anticipated that treating clinicians will be able to use OSI data to counsel patients when prescribing pharmaceutical drugs to lessen their OS levels and hence their ADRs.

\section{REFERENCES}

Alhawassi TM, Krass I, Bajorek BV, Pont LG. (2014). A systematic review of the prevalence and risk factors for adverse drug reactions in the elderly in the acute care setting. Clin Interventions in Aging; 4(9):2079-2086.

Alomar MJ (2014). Factors affecting the development of adverse drug effects. Saudi Pharm J; 22:83-94.

Balmus IR, Ciobica A, Antioch I, Dobrin R, Timofte D. (2016). Oxidative stress implications in the affective disorders: Main biomarkers, animal models relevance, genetic perspectives and antioxidant approaches. Oxidative Med Cell Long; doi.org/10.1155 /2016/3975101. Accessed October 1, 2019.

Caffo M, Caruso G, La Fata G, Barresi V, Visalli M, Venza M, Venza I (2014). Heavy metals and alterations in brain tumors. Current Genomics; 15:457-463.

Cahill DF, Elder JA (Eds) (1984). Biological effects of radiofrequency radiation. U.S. Environmental Protection Agency, Research Triangle, NC. EPA Report No. EPA-600/8-83-026F.

Clavenna A, Bonati M (2008). Adverse drug reaction in childhood: a review of prospective studies and safety alerts. Arch Dis Child. 94:724728.

Csoka AB, Szyf M (2009). Epigenetic side-effects of common pharmaceuticals: a potential new field in medicine and pharmacology. Med Hypothesis; 73(5):770-780.

De Boer A, van Hunsel F, Bast A (2015) Adverse food-drug interactions. Regulatory Toxicol Pharmacol 73:859-865.

Dorothy KS, Perel JM, Helsel JC, Wisner KL (2008). Changes in antidepressant metabolism and dosing across pregnancy and early postpartum. Psychiatry; 69(4):652-658. 
Du W, Rani R, Sipple J, Schick J, Myers KC, Mehta P, et al. (2019). The FA pathway counteracts oxidative stress through selective protection of antioxidant defense gene promoters. Blood; 119(18):4142-41-51.

Fisseler-Eckhoff A, Bartsch H, Zinsky R, Schirren J (2011). Environmental isocyanate-induced asthma: Morphologic and pathogenetic aspects of an increasing occupational disease. In J Environ Res Public Health; 8:3672-3687.

Gochfeld M. (2017). Sex differences in human and animal toxicology: toxicokinetics. Toxicol Pathol; 45(1):172-189.

Grova N, Schroeder H, Olivier JL, Turner JD (2019). Epigenetic and neurological impairments associated with early life exposure to persistent organic pollutants. Int J Genomics; 2019:2085496. doi: 10.1155/2019/2085496. Accessed October 2, 2019

Grzybowski A, Zulsdorff M, Wilhelm J, Tonagel F. (2015). Topic optic neuropathies: an updated review. Acta Ophthamol; 93(5):402-410.

Gunther M, AL Nimer F, Piehl F, Risling M, Mathiesen T. (2018) Susceptibility to oxidative stress is determined by genetic background in neuronal cell cultures. eNeuro; 5(2):e0335-17.2018:1-13. Accesses October 2, 2019

Hoetzenecker W, Nageli M, Mehra ET, Jensen AN, Saulite I, SchmidGrendelmeier P, et al. (2016). Adverse cutaneous drug eruptions: current understanding. Semin Immunopathol; 38(1):75-86.

Hou L, Zhang X, Wang D, Baccarelli A. (2012)/ Environmental chemical exposures and human epigenetics. Int J Epidemiol; 41:79-105.

Hukkanen J, Jacob P, Benowitz NL (2005). Metabolism and disposition kinetics of nicotine. Pharmacol Rev 57:79-115.

Ikemura M, Nishikawa M, Kusamori K, Yamashita F, Hashita M. (2013). Pivotal of oxidative stress in tumor metastasis under diabetic conditions in mice. J Control Release; 170(2):191-197.

Kacevska M, Ivanov M, Ingelman-Sundberg M. (2011): Perspectives on epigenetics and its relevance to adverse drug reactions. Clin Pharm Therapeutics; doi:10.1038/dpt.2011.21. Accessed Occtober 2, 2019.

Kaufmann CP, Stampfli D, Hersberger KE, Lampert ML. Determination of risk factors for drug-related problems: a multidisciplinary triangulation process. BMJ Open (2015). 5:e006376. doi:10.1136/bmjopen-2014006376.

Kramer MS. (1981) Difficulties in assessing the adverse effects of drugs. Br J Clin Pharmac; 11:105S-110S. Accessed October 2, 2019.

Kroschinsky F, Stozel F, von Bonin S, Beutel G. Kochanek M, Kiehl M, et al. (2017). New drugs, new toxicities: severe side effects of modern targeted and immunotherapy of cancer and their mangement. Crit Care; 21(1):89.

Lauschke VM, Ingelman-Sundberg M. (2016). The importance of patientspecific factors for hepatic drug response and toxicity. Int J Mol Sci; 17:1714. doi:10.3390/ijms 17101714 Accessed October 2, 2019.

Lee YM, Jacobs Jr DR, Lee DH (2018). Persistent organic pollutants and type 2 diabetes: a critical review of review articles. Frontiers in Endocrinol; 9 | articel 712. doi: 10.3389/fendo.2018.00712. Accessed October 2, 2019.

Legato MJ. (1998). Women's health: not for women only. Int J Fert. 43:6572.

Lind PM, Salihovic S, Stubleski J, Karrman A, Lind LL (2019). Association of exposure to persistent organic pollutants with mortality risk. JAMA Network Open; 2(4):e193070. doi:10.1001/jamanetworkopen.2019.3070. Accessed October 2, 2019.

Megha K, Deshmukh PS, Banerjee BD, Tripathi AK, Ahmed R, Abegaonkar MP. (2015) Low intensity microwave radiation induced oxidative stress, inflammatory response and DNA damage in rat brain Neurotoxicol; 51:158-165.

Mendrick DL, Diehl AM, Topor LS, Dietert RR, Will Y, La Merrill MA, et al. (2018). Metabolic syndrome and associated diseases: From the bench to the clinic. Toxicol Sci; 162(1): 36-42.

Nielsen F, Mikkelsen BB, Andersen HR, Grandjean P (1997), Plasma malondialdehyde as a biomarker for oxidative stress: reference interval and efforts of life-style factors. Clin Chem; 43(7):1209-1214.

Pimohamed M, Park BK. (2001). Genetic susceptibility to adverse drug reactions. Trends Pharmacol Sci; 22(6):298-305.

Reuter S, Gupta SC, Chaturvedi MM, Aggarwal BB. (2010): Oxidative stress, inflammation and cancer: how are they related? Free Rad Biol Med; 49(11):1608-1616.

Simco M, Mattsson MO (2004). Extremely low frequency electromagnetic fields as effectors of cellular responses in vitro: possible immune cell activation. J Cell Biochem; 93(1):82-93.

Sushko I, Salmina E, Potemkin VA, Poda G, Tetko IV. (2012). Tox alerts: A web server of structural alerts for toxic chemicals and compounds with potential adverse reactions. J Chem Infor Modeling; 52:23102316. Accessed October 2, 2019.
Vodovar D, Le Beller C, Lillo-Le-Louet A, Hanslik T, Megarbane B. (2014). rug-induced fever: a diagnosis to remember. Rev Med Interne (35(3):183-188,

Yegambaram M, Manivannan, Beach TG, Halden RU (2015): Curr Alzheimer Res 12:116-146.

Zeliger HI (2003). Toxic effects of chemical mixtures. Arch Environ Health; 58(1):23-29.

Zeliger HI (2011). Human toxicology of chemical mixtures, 2nd ed. Elsevier, London.

Zeliger HI (2016). Predicting disease onset in clinically healthy people. Inderdiscip Toxicol; 9(2):39-54

Zeliger HI (2019). Zeliger HI. Oxidative stress index: Disease onset prediction and prevention. EC Pharmacol Toxicol 7.10 (2019): 1022 1036. Accessed October 2, 2019.

Zeliger HI, Lipinski (2015). Physiochemical basis of human degenerative disease. Interdiscip Toxicol; 8(1):15-21. 